\title{
Vaihtoehto itsekkäälle ihmiselle
}

\author{
Menneisyys ja nykyisyys eivät kokonaan määrittele tulevaisuutta. \\ Olemme viimeinen sukupolvi, joka voi estää ilmastonmuutoksen \\ valloilleen pääsyn, uskovat vuoden tiedeartikkelin kirjoittajat \\ Arto O. Salonen ja Maria Joutsenvirta.
}

ILMASTOAHDISTUS SYVENEE, mutta Aikuiskasvatuksen vuoden 2018 tiedeartikkelista palkitut tutkijat eivät luovuta.

"Tulevaisuutta voidaan tehdä, jos on toimintatahtoa. Halusimme haastaa itsemme tunnistamaan ennakkoluulottomasti niitä arvoja, ja arvoista seuraavia tekoja, joiden varaan hyvä tulevaisuus rakentuu", Arto O. Salonen sanoo.

Artikkelissaan ”Vauraus ja sivistys yltäkylläisyyden ajan jälkeen" Salonen ja Joutsenvirta näyttävät, kuinka hyvä tulevaisuus voidaan tehdä todeksi.

Eletään vuotta 2050. Siihen mennessä yhteiskuntien on määrä olla hiilidioksineutraaleja. Tutkimus kumpusi siitä ajatuksesta että pohjoismaiset hyvinvointiyhteiskunnat voivat olla suunnannäyttäjiä globaalissa kestävyyshaasteessa.

"Muutoksessa kysytään ratkaisuja, jotka läpäisevät yhteiskunnan eri osa-alueita ja kansalaisten arkea. Joku ne ratkaisut kehittää, ennemmin tai myöhemmin. Se joku voi olla Suomi, jos niin halutaan", Salonen sanoo.

\section{LAAJA KATSE TULEVAISUUTEEN}

Muutos vaatii näkökulman avartamista. Tarvitaan tulevaisuusnäkyjä, jotka puhuttelevat ihmisiä syvällisemmin

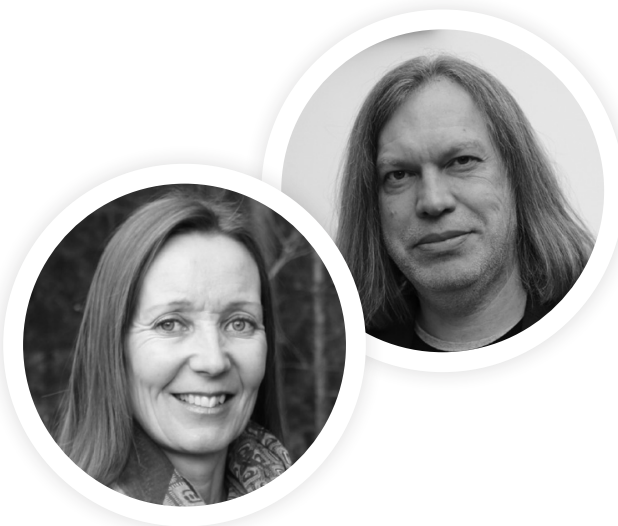

Maria Joutsenvirta ja Arto O. Salonen kutsuvat kansalaiset ja päättäjät tulevaisuusdialogiin.

kuin älyllisesti, saavat aikaan liikahduksen syvimmässä ja sen myötä muutoksia ajattelussa ja toiminnassa.

”On tärkeä yhdistää sivistyksen, kasvatuksen ja talouden näkökulmat, kun laajennetaan ymmärrystä siitä, mitä edistys pohjimmiltaan tarkoittaa Suomen kaltaiselle hyvinvointiyhteiskunnalle", Maria Joutsenvirta sanoo.

Kaksikko viitoittaa tietä edistykselle, joka karttaa kapeita taloudellisia määritelmiä ja avaa kokonaisvaltaisen näkymän hyvän elämän tavoittelulle. 


\section{Raadin perustelut}

Arto O. Salonen ja Maria Joutsenvirta katsovat vuoteen 2050 hyödyntämällä utopistista tulevaisuusmuistelua. He rakentavat systeemiajatteluun nojaavan ideaalin, joka ankkuroituu jälkimaterialistisiin arvoihin ja ekososiaaliseen sivistykseen. Artikkeli vauhdittaa ratkaisukeskeistä ajattelua kestävän tulevaisuuden rakentamisessa.

Aikuiskasvatuksen valtavirrasta poikkeava tiedeartikkeli on aiheeltaan tärkeä, humaanisti kirjoitettu ja tieteellisesti vakuuttava. Se kantaa mukanaan vakuuttavaa filosofista pohdintaa.

Kirjoittajat luovat kuvan yhteiskunnasta, jossa yksilö pystyy liittämään oman elämänsä johonkin itseä suurempaan. He hakevat vaihto- ehtoa itsekkäälle, vain omaa aineellista hyötyään maksimoivalle homo economicukselle. Artikkelissa paikannetaan kansallinen keikahduspiste, joka johtaa arvokkaan ja merkityksellisen, ekososiaalista sivistystä ruokkivan elämäntavan löytymiseen. Tulevaisuusvisioon kuuluvat demokratian, osallisuuden ja aktiivisen kansalaisuuden lisääminen digitalisaation ja tekoälyn avulla.

Kirjoittajat hyödyntävät ansiokkaasti klassikoita, kuten Erik Allardtin hyvinvointitutkimuksia ja Abraham Maslowin tarvetutkimuksia, sekä tuoretta tutkimuskirjallisuutta, kuten Ronald Inglehartin ajatuksia jälkimateriaalisista arvoista ja kulttuurimuutoksen hiljaisesta vallankumouksesta sekä Shalom H. Schwartzin arvoteorioita.
"Kirjoittajat hakevat vaihtoehtoa itsekkä̈lle, vain omaa aineellista hyötyään maksimoivalle "homo economicukselle", Aikuiskasvatuksen toimituskunta toteaa.

Salonen ja Joutsenvirta luovat kuvan yhteiskunnasta, jossa kansalaisista tulee tulevaisuuden tekijöitä siten, että he liittävät elämänsä osaksi ratkaisujen ketjuja. Ratkaisuksi asettumalla elämä saa merkityssisällön.

\section{TULEVAISUUSDIALOGIA LAAJALLA POHJALLA}

Itä-Suomen yliopiston apulaisprofessorina toimiva Arto O. Salonen osallistuu aktiivisesti yhteiskunnalliseen keskusteluun: kolumnoi Opettaja-lehdessä, toimii Suomen kestävän kehityksen paneelissa ja luennoi kuntapäättäjille. Siihen on syynsä.

"Olemme viimeinen sukupolvi, joka voi itse itseään kiihdyttävän ilmastonmuutoksen valloilleen pääsyn vielä estää. Hyvän jatkumisen turvaaminen motivoi joka päivä etsimään ratkaisuja”, hän perustelee.

Maria Joutsenvirta on kestävän talouden tutkija Aalto-yliopistosta. Hän on kokenut perinteisen tutkijan tehtävän ja roolin ristiriitaiseksi suhteessa siihen, miten nopeita ja radikaaleja ratkaisuja globaaleissa ongelmissa tarvitaan.

"Kun tavoitellaan järjestelmätason muutosta, tieteellinen metodi ei ole kovin tehokas. Muutos tarvitaan tavassa, jolla eri toimijat ja tiedon lajit ovat suhteessa toisiinsa."

Tietoja, tunteita, aisteja, oivalluksia ja intuitiota hyödyntävä systeeminen yhteiskehittely toimii Joutsenvirran kokemuksen mukaan näin. Se vahvistaa kykyä nähdä uusia yhteyksiä ja valaa rohkeutta isoihinkin muutoksiin.

Vuoden tiedeartikkelin kirjoittajat ovat yksimielisiä siitä, että hyvä tulevaisuus vaatii instituutioiden rajat ylittävää vuorovaikutusta. He haastavatkin niin kansalaiset kuin päättäjät tulevaisuusdialogiin.

"Vastakkainasetteluihin ja väittelyyn perustuva keskustelu lamaannuttaa ja lisää ahdistusta. Yhteiskunnassa tarvitaan enemmän kuunteluun perustuvia kollektiivisia tiloja asioiden käsittelylle. On hyvä, että dialogista keskustelukulttuuria vahvistetaan”, Maria Joutsenvirta sanoo. 